\title{
Influence of surface and subsurface heterogeneity on observed borehole temperatures at a mountain permafrost site in the Upper Engadine, Swiss Alps
}

\author{
S. Schneider, M. Hoelzle, and C. Hauck \\ Alpine Cryosphere and Geomorphology (ACAG), Department of Geosciences, University of Fribourg, Switzerland \\ Correspondence to: S. Schneider (sina.schneider@unifr.ch)
}

Received: 7 September 2011 - Published in The Cryosphere Discuss.: 11 October 2011

Revised: 7 March 2012 - Accepted: 22 March 2012 - Published: 19 April 2012

\begin{abstract}
Compared to lowland (polar) regions, permafrost in high mountain areas occurs in a large variety of surface and subsurface materials and textures. This work presents an eight-year (2002-2010) data set of borehole temperatures for five different (sub-) surface materials from a high alpine permafrost area, Murtèl-Corvatsch, Switzerland. The influence of the material on the thermal regime was investigated by borehole temperature data, the temperature at the top of the permafrost (TTOP-concept) and the apparent thermal diffusivity (ATD). The results show that during the last eight years, material-specific temperature changes were more significant than climate-induced temperature trends. At coarse blocky, ice-rich sites, no changes in active layer depth were observed, whereas the bedrock and the fine-grained sites appear to be highly sensitive to changes in the microclimate. The results confirm that the presence and growth of ice as well as a thermally driven air circulation within the subsurface are the key factors for the occurence and preservation of alpine permafrost.
\end{abstract}

\section{Introduction}

\subsection{General setting}

Since work on high altitude permafrost distribution started in the 1970s (Barsch, 1977; Haeberli et al., 1988), one of the challenging problems is the heterogeneity of mountain permafrost in terms of its microclimate, snow cover and subsurface material, which makes a direct comparison of different permafrost sites almost impossible. If this heterogeneity and its influence on the thermal regime of the per- mafrost is known, the accuracy of spatially distributed permafrost models based on topoclimatic factors could be verified. In this contribution, eight-year time series of seasonal and inter-annual borehole temperature variability within a small $\left(1 \mathrm{~km}^{2}\right)$ high mountain permafrost region with different surface and subsurface materials is presented. Local climatic factors (such as air temperature, wind speed and direction, relative humidity and incoming solar radiation) as well as the topographic situation (exposition, slope angle) are assumed to be the same for all boreholes. Hence, observed differences in subsurface temperatures are mostly due to the different subsurface materials and their corresponding materialdependent, dominant processes. Since the aim of this work is to understand the different processes occuring in high mountain permafrost and to estimate the different sensitivities to changes in the microclimate, this work is focused on (1) the characterisation of the thermal regimes for different materials based on borehole temperature data from 2002-2010, (2) an analysis of the relationship between air temperature and subsurface temperature by using the extended TTOP concept, and (3) an evaluation of the thermal response of the different subsurface materials by calculating the temperature transfer rate and the apparent thermal diffusivity.

\subsection{Research context}

In high moutain permafrost, the thermal regime of the active layer strongly depends on site-specific factors like the albedo, emissivity, surface roughness, grain size, pore volume, composition and type of material, as well as climatic factors such as air temperature, incoming radiation and precipitation. As long as the surface of the bedrock is not 
covered by coarse or fine material and no snow is present, the thermal regime of the ground is directly coupled with the atmosphere (Williams and Smith, 1989), and the heat will mainly be transferred by conduction and advection of meltwater (Wegmann et al., 1998; Gruber and Haeberli, 2007; Krautblatter and Hauck, 2007).

In addition to temperature rise and phase changes of ice to water, permafrost degradation in bedrock is influenced by frost weathering leading to a reduction of rock strength (Harris et al., 2009) as well as by advective process by percolating meltwater. The degradation by advection can destabilize much greater volumes of rock than conduction within the same time (Gruber and Haeberli, 2007). Air-ventilation within clefts can cause a lowering of the temperature of about $1.5^{\circ} \mathrm{C}$ within strongly fractured, near-vertical bedrock (Hasler et al., 2011). If the bedrock is covered by vegetation and soil, the thermal response of the active layer to surface temperatures will be damped. Moss and organic matter affect the hydrological properties, as they increase the water holding capacity of the soil (Walker et al., 2003).

If a buffer layer of coarse blocky material is present, density differences and processes like wind pumping lead to an exchange of air masses within the ground and enhance convective and advective air flows (Hanson and Hoelzle, 2004; Panz, 2006). Gruber and Hoelzle (2008) assume that a porosity of $40 \%$ can reduce the thermal conductivity by about an order of magnitude compared to bedrock. One of the best known phenomenon within coarse blocky material is the cooling effect of reversible air circulation, which is called "balch-effect" (Balch, 1900; Harris and Pedersen, 1998) within flat areas and "chimney-effect" within slopes (described e.g. in Wakonigg, 1996; Harris and Pedersen, 1998; Sawada et al., 2003; Delaloye et al., 2003). In general, it is assumed that the chimney-effect can only develop under thin, non-insulating snow cover conditions. In contrast, Delaloye and Lambiel (2005) and Morard et al. (2008) showed that even in the presence of a thick snow cover, the ascent of relatively warm air within a blocky slope can force the aspiration of cold air through the snow cover into the blocks, reducing the temperature of the lower part of the slope. This thermally driven ventilation can lead to a cooling of the subsurface by several degrees.

A fine-grained buffer layer with a highly permeable texture supports the advective heat transport by infiltrating (snowmelt-) water. Hinkel and Outcalt (1994) suppose that the warming of fine-grained permafrost material in arctic lowlands by advective processes exceeds those by conduction by one or two orders of magnitude. The gravity infiltration of meltwater may be enhanced by the transport of water and vapour in response to osmotic pressure gradients induced by relatively higher solute concentration at depth (Hinkel and Outcalt, 1994; Outcalt et al., 1990). Modelling the infiltration processes, Scherler et al. (2010) pointed out that the heat transport by percolating water is not negligible and seems to be a key factor to increase the temperature of the permafrost.
The snow cover as an additional seasonal buffer layer influences the thermal regime of the subsurface, mainly as the thermal resistance of the snow cover increases with increasing snow depth. Haeberli (1973), Keller and Gubler (1993), Hanson and Hoelzle (2004) observed in field studies and Luetschg et al. (2008) in a model study that effective thermal resistance exists at a snow depth of more than $0.6-0.8 \mathrm{~m}$. For constant air temperatures, an increase of snow depth by $1 \mathrm{~m}$ (starting with a $0.2 \mathrm{~m}$, non-insulating snow cover) can lead to an increase of the mean annual ground surface temperature (MAGST) by approximately $2.7^{\circ} \mathrm{C}$ (Luetschg et al., 2008). Gruber and Hoelzle (2008) pointed out that coarse blocky material can reduce the warming effect of the snow cover up to several degrees celsius due to the lower thermal conductivity close to the surface of the blocky layer. Furthermore, the duration and date of the first significant snowfall in autumn, and the date of the disappearance of snow in spring, are important factors in terms of the thermal regime of the entire year. In model experiments, Luetschg et al. (2008) showed that the longer the time span of a non-insultating snow cover, the colder the thermal regime of the entire year. Hereby, the cooling caused by delayed snowfall in autumn is within the same order of magnitude as the effect of delayed snowmelt in spring (Ling and Zhang, 2003; Luetschg et al., 2008).

\section{Investigation site and data sets}

The study area is situated in the Upper Engadin (Eastern Swiss Alps) at around $2700 \mathrm{~m}$ a.s.l. and is surrounded by a steep northwest facing rock wall (Fig. 1). Taking into account that the investigation of this area started in the 1970s (Barsch, 1977), it is now one of the best investigated permafrost areas in the Alps and part of the PERMOS network (Permafrost Monitoring Switzerland) (e.g. Haeberli et al., 1988; Hoelzle et al., 2002; Hanson and Hoelzle, 2005; PERMOS, 2010). Within the area, the Murtèl rock glacier is one of the dominant periglacial features, but further rock glaciers and talus slopes are present to the west (Fig. 2). The borehole network consists of a $58 \mathrm{~m}$ deep borehole drilled on the rock glacier Murtèl in 1987 (Haeberli et al., 1988), two boreholes drilled in 2002 on the nearby Chastelets rock glacier and three boreholes located in between (Hanson and Hoelzle, 2005). Though the climatic parameters can be assumed to be similar for all borehole sites, there is a strong variation in snow cover duration, snow depth as well as the subsurface material and ice content in which the boreholes are drilled.

\subsection{Air temperature measurements and snow height}

A micrometeorological station located at the Murtèl rock glacier measures air temperature, wind speed and direction, humidity, in- and outgoing longwave radiation, in- and outgoing shortwave radiation and the height of the snow cover since January 1997 (Mittaz et al., 2000). Data were recorded 


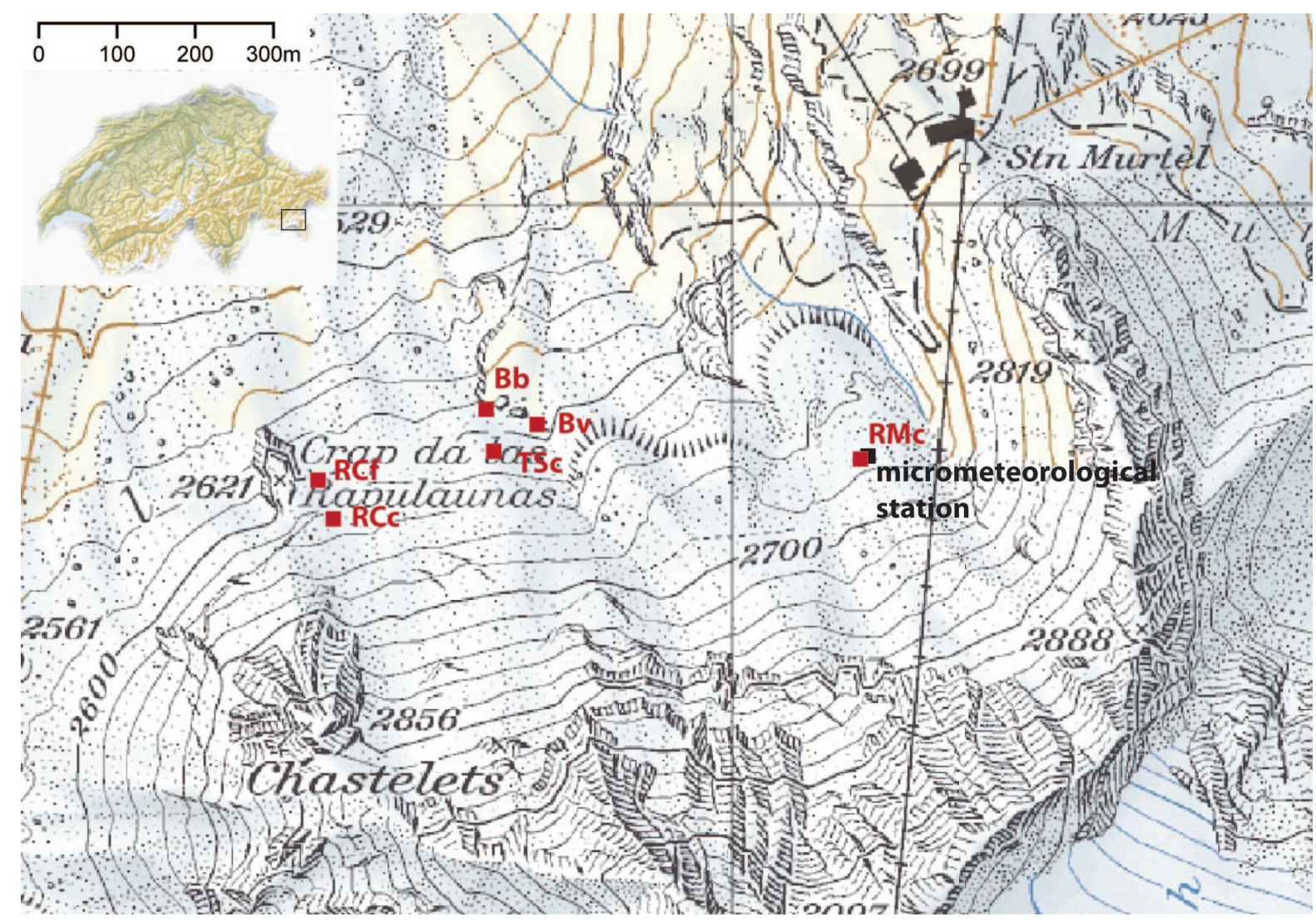

Fig. 1. Investigation area Murtèl-Corvatsch, Eastern Swiss Alps. The 5 shallow boreholes are indicated by its material: $\mathrm{Bb}=\mathrm{bare}$ bedrock, $\mathrm{Bv}=$ vegetated bedrock, TSc $=$ talus slope (coarse blocky), $\mathrm{RCf}=$ rock glacier Chastelets (fine-grained), $\mathrm{RCc}=$ rock glacier Chastelets $(\mathrm{coarse}$ blocky) and RMc rock glacier Murtèl (coarse blocky).

every $10 \mathrm{~min}$ and logged as means over $30 \mathrm{~min}$ intervals. Since 2010 the data have been stored at hourly intervals. From 1988 until 2006, the mean annual air temperature (MAAT) was $-1.8^{\circ} \mathrm{C}$ and the avarage height of snow was $0.41 \mathrm{~m}$ (Hoelzle and Gruber, 2008). During the snow covered period, the ground surface temperature (GST) is estimated by an IR-thermometer, which was added to the micrometeorological station in 2001 (Hoelzle and Gruber, 2008). The micrometeorological measurements at Murtèl rock glacier were considered to be representative for the whole study area. However, to estimate the exact duration of the snow cover at each borehole site, GST measurements were used, as the threshold of the daily temperature amplitude of $0.4{ }^{\circ} \mathrm{C}$ indicates whether snow is present $\left(\leq 0.4^{\circ} \mathrm{C}\right)$ or not $\left(\geq 0.4^{\circ} \mathrm{C}\right)$. The height of the snow cover was either measured by the micrometeorological station (for RMc) or estimated by temperature loggers (i-buttons, Lewkowicz, 2008), placed at different depths on a snowpole next to the boreholes (for $\mathrm{Bv}, \mathrm{Bb}$ and $\mathrm{RCf}$ ).

\subsection{Ground surface and subsurface temperature mea- surements}

A temperature sensor placed at the surface next to each borehole (Hanson and Hoelzle, 2005) was used to obtain the GST for each borehole separately.

Subsurface temperatures were measured by temperature sensors placed within the six boreholes (Fig. 2). The borehole at the Murtèl rock glacier (RMc) was drilled in coarse blocky material. Thermistors were placed down to $58 \mathrm{~m}$ depth, starting at $0.5 \mathrm{~m}$ and seperated by $1 \mathrm{~m}$. The five boreholes which were drilled by Hanson and Hoelzle (2005) are each $6 \mathrm{~m}$ deep and equipped with 18 thermistors placed every $10 \mathrm{~cm}$ within the uppermost meter, every $0.5 \mathrm{~m}$ from 1 to $5 \mathrm{~m}$ and at $6 \mathrm{~m}$ depth. Two of these boreholes were drilled in bedrock (one on bare bedrock $(\mathrm{Bb})$, the other one covered by $19 \mathrm{~cm}$ of soil and vegetation (Bv)), one was situated on a coarse blocky talus slope (TSc), one was drilled in the finegrained material of the Chastelets rock glacier close to its front (RCf) and the last one was located in the coarse blocky part of the Chastelets rock glacier (RCc) (Fig. 2). 

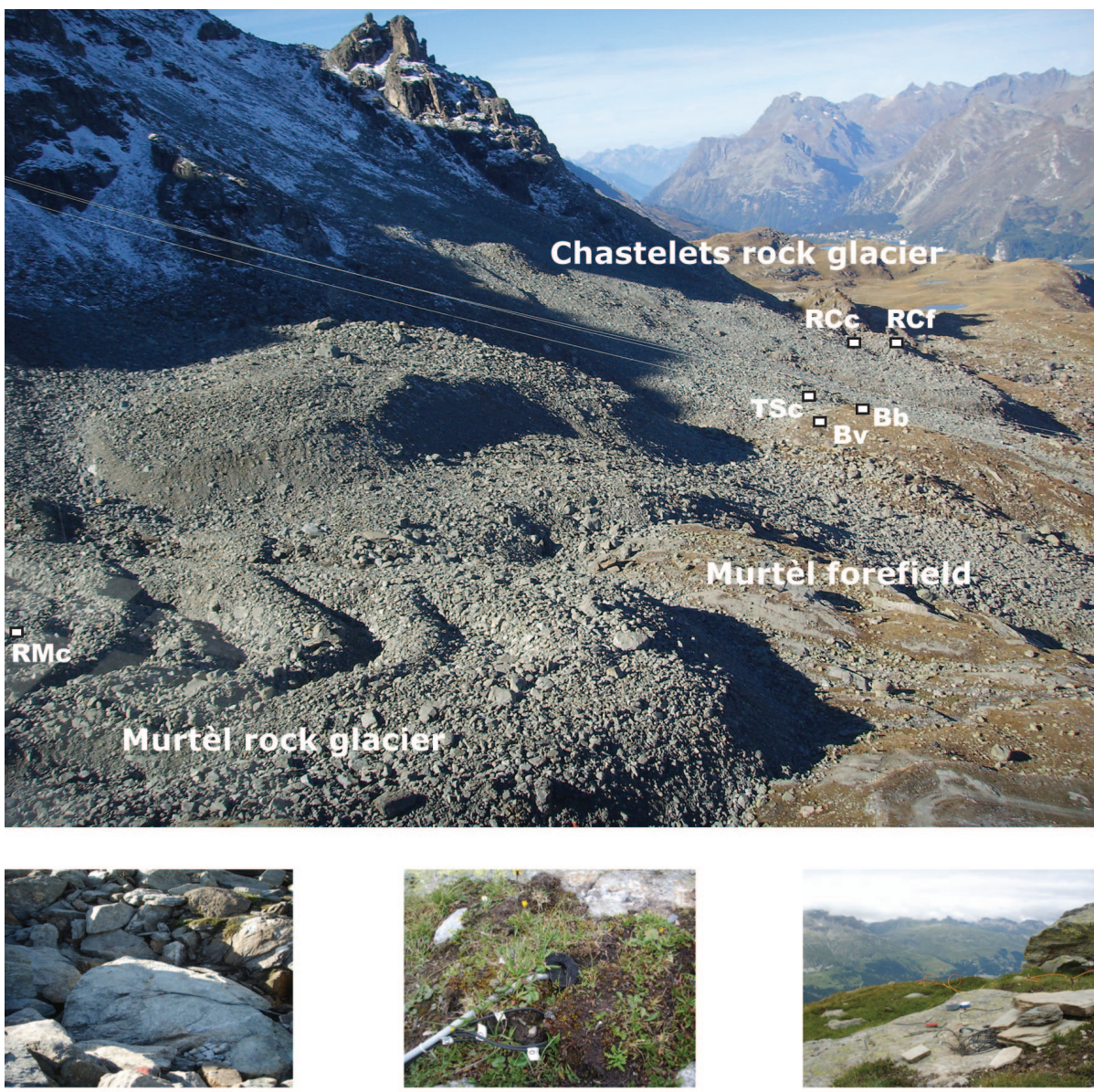

rock glacier "Murtèl" (coarse blocky) (RMc)

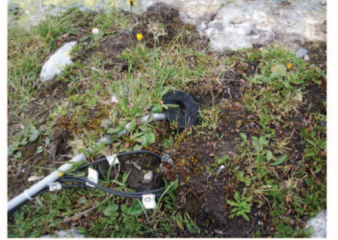

bedrock (vegetated) (Bv)

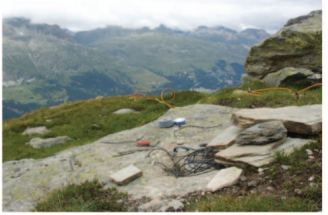

bedrock (bare) $(\mathrm{Bb})$

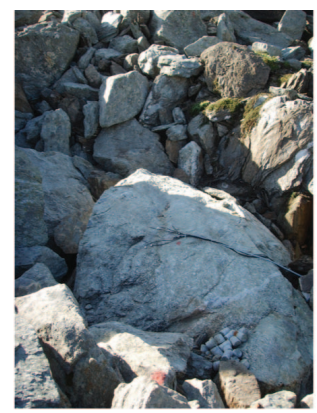

rock glacier "Chastelets" (coarse blocky) (RCc)

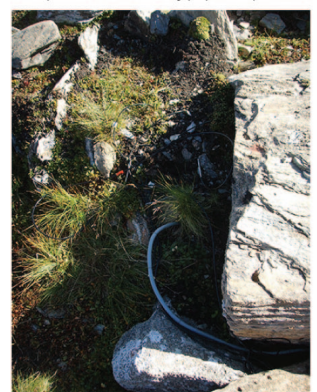

rock glacier "Chastelets" (fine grained) (RCf)

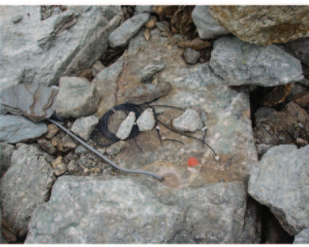

talus slope (coarse blocky) (TSc)

Fig. 2. Photographs of the different surfaces at the borehole locations in the investigation area, taken in summer 2009.

\section{Data processing}

As a means to analyse the relative influence of different subsurface materials on the thermal regime, the relationship between air temperature and subsurface permafrost temperature can be estimated by using the extended TTOP-concept (Smith and Riseborough, 1996; Herz et al., 2003; Hoelzle and Gruber, 2008). The TTOP-concept was developed to explain the climate-permafrost relationship and describes the offset between the mean annual air temperature (MAAT) and the temperature at the top of the permafrost (TTOP) (Smith and Riseborough, 1996). To take into account the surface heterogeneity in mountain areas, the MAGST was added. The total offset between the air temperature and the temperature of the permafrost is expressed by an offset between MAAT and MAGST and an offset between MAGST and TTOP. Hoelzle and Gruber (2008) recommend to include a third temperature value, the mean annual surface temperature (MAST), which is the thermal infrared radiating temperature of the ground surface, measured by an IR thermometer. Therefore, the surface offset has to be partitioned into the offset between MAAT and MAST, and another between MAST and MAGST. This concept is particularly important for mountain permafrost environments, because the duration and the height of snow cover as well as its influence on the surface temperature can be taken into account. To simplify the comparison of the temperature data within the different sites, a low-pass Gaussian filter was applied to the air temperature and the ground surface temperature. As it reduces highfrequency variations along the time series, this filter allows to identify temporal variations and trends. For annual subsurface temperatures below $2 \mathrm{~m}$ depth, a 365-day movingaverage was applied.

Data processing is done individually for each season according to Delaloye (2004), Hanson and Hoelzle (2004). As the seasonally varying microclimatic parameters such as snow cover and infiltrating meltwater can be site specific, it is important to adapt the seasons separately for each site, according to the dominant processes and not solely with respect to a fixed date. Phases 1-2 are defined by temperatures below $0{ }^{\circ} \mathrm{C}$ but without the existence of an insulating snow cover. Phase 3 is characterized by a snow cover, which is 
thick enough to decouple the air temperature from the GST. Phase 4 is characterized by the impact of the meltwater leading to the zero curtain (i.e. maintaining temperatures near $0^{\circ} \mathrm{C}$ for a considerable length of time due to the release of latent heat); whereas phase 5 is defined as the time between the end of the spring zero curtain and the first time in autumn when the surface temperature drops below $0^{\circ} \mathrm{C}$. The thresholds used to determine the phases in this study are shown in Table 1.

To estimate the thermal response of the different subsurface materials, a cumulative freezing/thawing temperature gradient (CFTG/CTTG), the apparent thermal diffusivity and the temperature transfer rate, was calculated for all sites for the period between 2003-2010. The cumulative freezing temperature gradient quantifies the amount of freezing in $\mathrm{K}$ per day and was estimated by the division of the cumulative freezing degree days $(\mathrm{K})$ by the amount of freezing days $\left(\mathrm{d}^{-1}\right)$ during the annual cooling period (see above Phases 12). The cumulative thawing temperature gradient (CTTG) was calculated in the same manner but for Phase 5 .

The thermal diffusivity describes how fast a material can change its temperature. It is expressed by the ratio of thermal conductivity to heat capacity. Its variations can be interpreted in terms of phase changes in the subsurface. In unfrozen material, increasing water content leads to an increase of the thermal diffusivity, which is due to a more rapid increase of conductivity than of heat capacity (Williams and Smith, 1989). Pogliotti et al. (2008) pointed out that the key factor of the ATD is the water content. In frozen materials, especially within the temperature range from 0 to $-3^{\circ} \mathrm{C}$, the diffusivity is highly temperature dependent and is dominated by the heat capacity term (Williams and Smith, 1989). Note that estimating the thermal diffusivity by borehole temperature data includes the effect of non-conductive heat transfer including water vapour transport and release of latent heat (apparent thermal diffusivity). Assuming that the temperature pattern can be described by an elementary sinusoidal function, the ATD was calculated by the yearly temperature amplitude according to Williams and Smith (1989) by

$k=\frac{\omega\left(z_{1}-z_{2}\right)^{2}}{2\left[\ln \left(\frac{A_{1}}{A_{2}}\right)\right]^{2}}$,

where $k$ is the thermal diffusivity $\left[\mathrm{m}^{2} \mathrm{~s}^{-1}\right], \omega$ the signal frequency $\left[\mathrm{s}^{-1}\right.$ ] and $A 1$ and $A 2$ are the temperature amplitudes $[\mathrm{K}]$ at the depths $z_{1}$ and $z_{2}[\mathrm{~m}]$.

The temperature transfer rate $\left(T_{\mathrm{R}}\right)$ describes the temperature change within the active layer with time by

$T_{\mathrm{R}}=\frac{\left(\frac{\Delta T}{\Delta t}\right)}{\left(z_{1}-z_{2}\right)}$,

with:

$\Delta T=T_{\operatorname{Max} 1}-T_{\operatorname{Max} 2} ;$
Table 1. Thresholds to differentiate the yearly phases individually at each borehole.

\begin{tabular}{lcccc}
\hline Threshold & $1-2$ & 3 & 4 & 5 \\
\hline $\begin{array}{l}\text { Daily mean air } \\
\text { temperature }\end{array}$ & $<0{ }^{\circ} \mathrm{C}$ & $<0{ }^{\circ} \mathrm{C}$ & $\geq 0{ }^{\circ} \mathrm{C}$ & $\geq 0{ }^{\circ} \mathrm{C}$ \\
$\begin{array}{l}\text { Daily amplitude } \\
\text { of GST }\end{array}$ & $\geq 0.4{ }^{\circ} \mathrm{C}$ & $\leq 0.4{ }^{\circ} \mathrm{C}$ & $=0^{\circ} \mathrm{C}$ & $\geq 0.4{ }^{\circ} \mathrm{C}$ \\
Snow height $(d)$ & $0<d \leq 30 \mathrm{~cm}$ & $>30 \mathrm{~cm}$ & - & - \\
\hline
\end{tabular}

$\Delta t=t_{T_{\mathrm{Max} 1}}-t_{T_{\mathrm{Max} 2}}$

The temperature change with depth $(\Delta T[\mathrm{~K}])$ is expressed as the temperature difference between the annual maximum temperature at depth $1\left(T_{\mathrm{Max} 1}\right)$ and depth $2\left(T_{\mathrm{Max} 2}\right)$, where $z_{1}=0.5 \mathrm{~m}, z_{2}=$ active layer depth [m], and $\Delta t$ is the time interval [d] between $T_{\mathrm{Max} 1}$ and $T_{\mathrm{Max} 2}$.

\section{Results}

\subsection{Eight years of active layer observation at the Murtèl-Corvatsch area}

The evolution of the subsurface temperature is shown for all six boreholes from 2002 until 2010 (Fig. reffig:temp8years). At all sites minimum winter temperatures were observed in $2004 / 2005$ and 2005/2006. In summer the bedrock sites (Fig. 3a and b) are unfrozen down to $6 \mathrm{~m}$ depth. During winter 2008/2009 and 2009/2010, the Bb site (Fig. 3a) did not freeze at all below $5 \mathrm{~m}$ depth. Seasonal temperature fluctuations at the surface of $\mathrm{Bb}$ are within a range of -13 to $25^{\circ} \mathrm{C}$.

Figure $3 \mathrm{c}$ shows the observed temperature evolution of the borehole drilled in the talus slope (TSc). The borehole is only $25 \mathrm{~m}$ away from the bedrock sites but it shows a completely different temperature regime: (1) permanently frozen conditions below $5 \mathrm{~m},(2)$ a smaller seasonal temperature variation, and (3) a variable active layer.

The rock glacier sites experience during winter the lowest temperatures within the permafrost body compared to the other sites. Seasonal temperature fluctuations at the surface are within a range of -15 until $28^{\circ} \mathrm{C}$ (Fig. 3d, e) and therefore similar to those of the bedrock sites.

Figure $3 \mathrm{~d}$ presents the temperature of the borehole, which is located at the front of the Chastelets rock glacier (RCf) and which is drilled in fine-grained material. Since 2009, no more permafrost was observed within the uppermost $6 \mathrm{~m}$. The thermal regime shows a similar pattern as that at the TSc site (Fig. 3c), but summer temperatures at the surface are lower.

To identify temperature variations during the measured period of time, the filtered temperature data are shown in Fig. 4. Neither the air temperature nor the GST or the temperature 

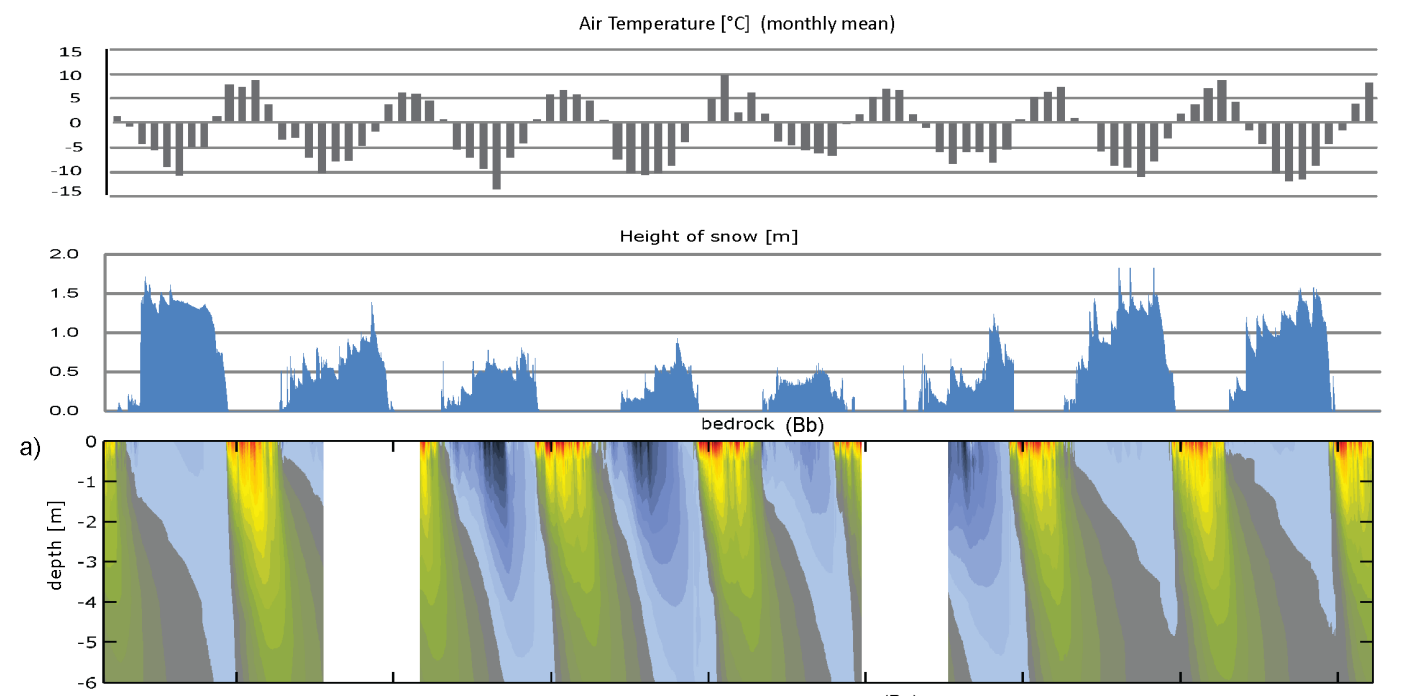

b)
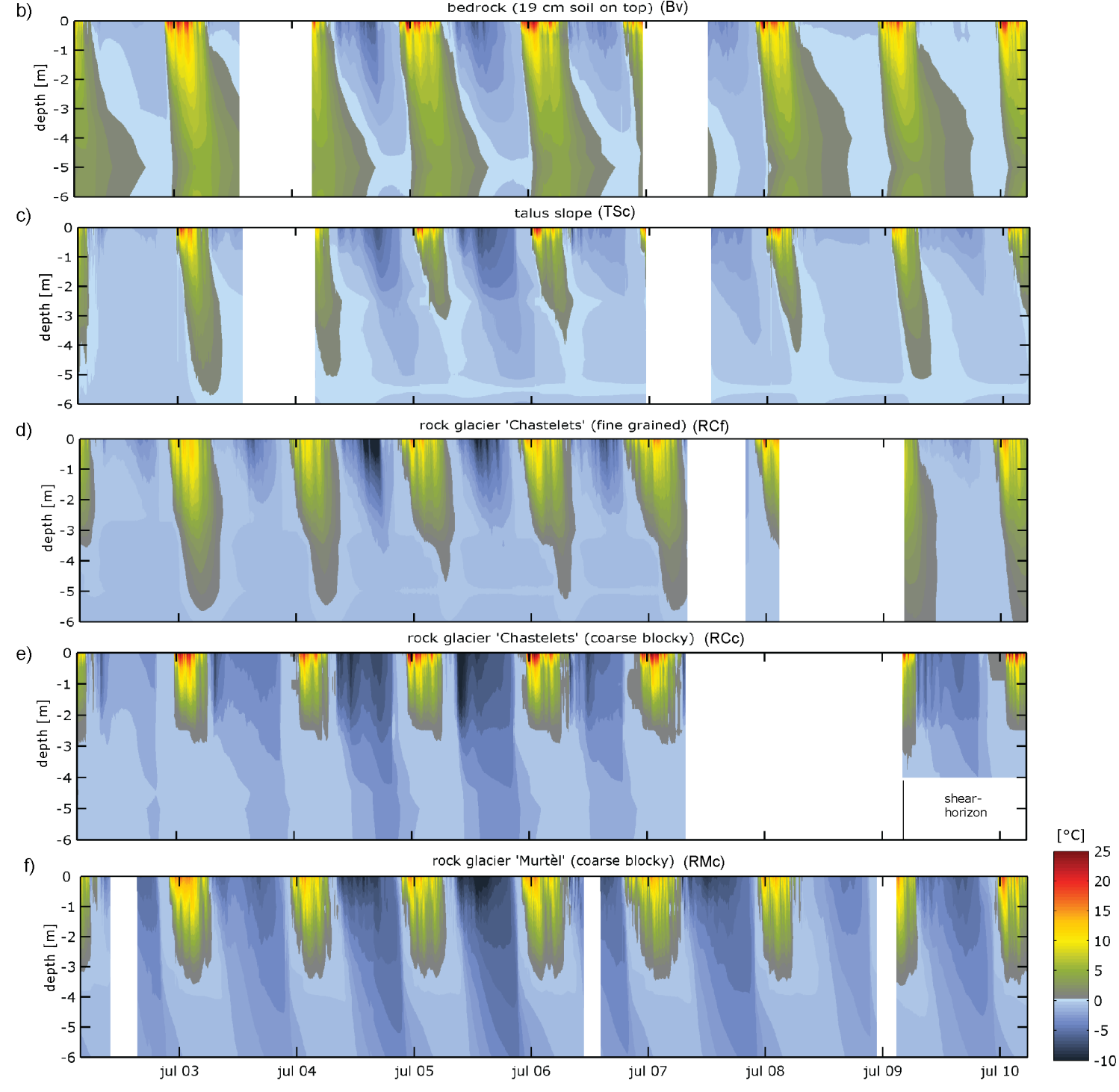

Fig. 3. Monthly mean air temperature, snow height and borehole temperature data from 2002-2010. Air temperature and snow height are measured by the micrometeorological station at the Murtèl rock glacier. 

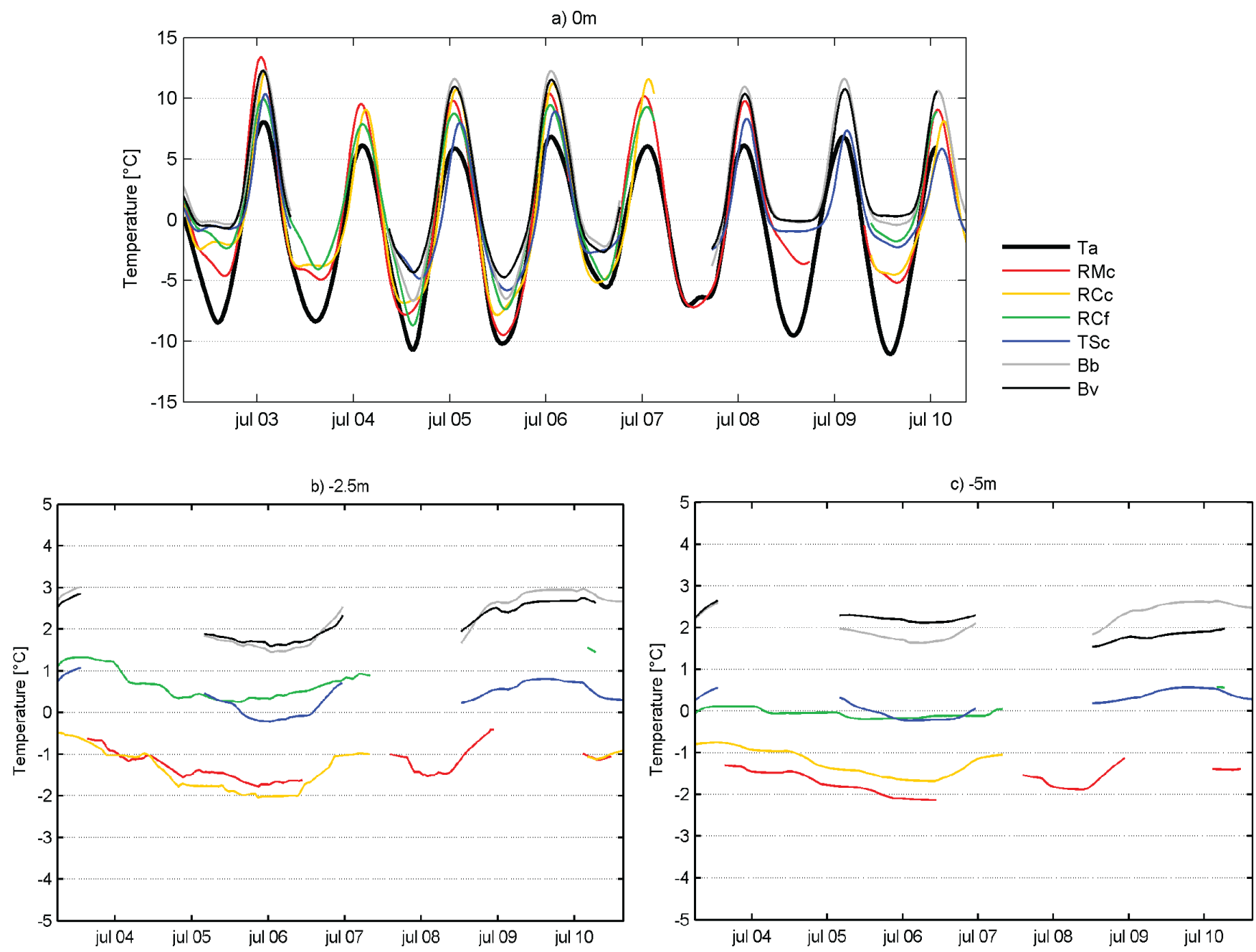

Fig. 4. Filtered temperatures from 2002-2010 for all sites and different depths: (a) air temperature and ground surface temperature, (b) subsurface temperature at $-2.5 \mathrm{~m}$, and (c) subsurface temperature at $-5 \mathrm{~m}$. For the air temperature and ground surface temperature, a low-pass Gaussian filter was applied (a), and for the subsurface temperatures (b) and (c) a 365-day moving-average was used. Data gaps are due to technical problems with the data logger.

below show significant trends between 2002-2010. At all sites from 2004 until 2006, a slight temperature reduction of about $1^{\circ} \mathrm{C}$ is recognizable at $2.5 \mathrm{~m}$ and $5 \mathrm{~m}$ depth (Fig. $4 \mathrm{~b}, \mathrm{c}$ ). From 2008 until 2009 , a temperature increase of about $1{ }^{\circ} \mathrm{C}$ is visible for RMc, and of about $0.5^{\circ} \mathrm{C}$ for the other sites but interrupted by the data gap. The temperature difference between GST and air temperature is much lower for a site with less snow (maximal $0.5 \mathrm{~m}$ ) than for a site with a snow cover of more than $1 \mathrm{~m}$ (Fig. 5).

Regarding the annual change of active layer depth (Fig. 6) from 2003 to 2010, two patterns can be distinguished: (a) the RCf and the TSc site, which show a high inter-annual variability, and (b) the coarse blocky rock glacier sites (RCc and $\mathrm{RMc}$ ), at which the active layer depth remains constant each year. For TSc a range of $3.5-5.5 \mathrm{~m}$ is remarkable, and for $\mathrm{RCf}$ the active layer depth varies between $4-6 \mathrm{~m}$. The year
2005 shows the shallowest active layer depth, whereas during the years 2003 and 2009, the depth was up to $6 \mathrm{~m}$ at the $\mathrm{RCf}$ and $5.5 \mathrm{~m}$ at the TSc site. The active layer depth of the course blocky rock glacier sites never exceeds $3 \mathrm{~m}(\mathrm{RCc})$ and $3.5 \mathrm{~m}(\mathrm{RMc})$, respectively.

\subsection{Influence of the subsurface material on the ground thermal regime}

Though all sites are influenced by the same meteorological input values, a high variation of the surface and subsurface temperatures was observed. Mean winter air temperature (defined according to Table 1 ) is $-6.5^{\circ} \mathrm{C}$ and mean summer air temperature is $5.2^{\circ} \mathrm{C}$, whereas GST differs from -4.9 $(\mathrm{RMc})$ to $-2.2{ }^{\circ} \mathrm{C}(\mathrm{TSc})$ in winter and from 5.7 (TSc) to $9.2^{\circ} \mathrm{C}(\mathrm{Bv})$ in summer. Comparing all sites, it becomes apparent that the bedrock sites (Fig. 7a and b) experience an 


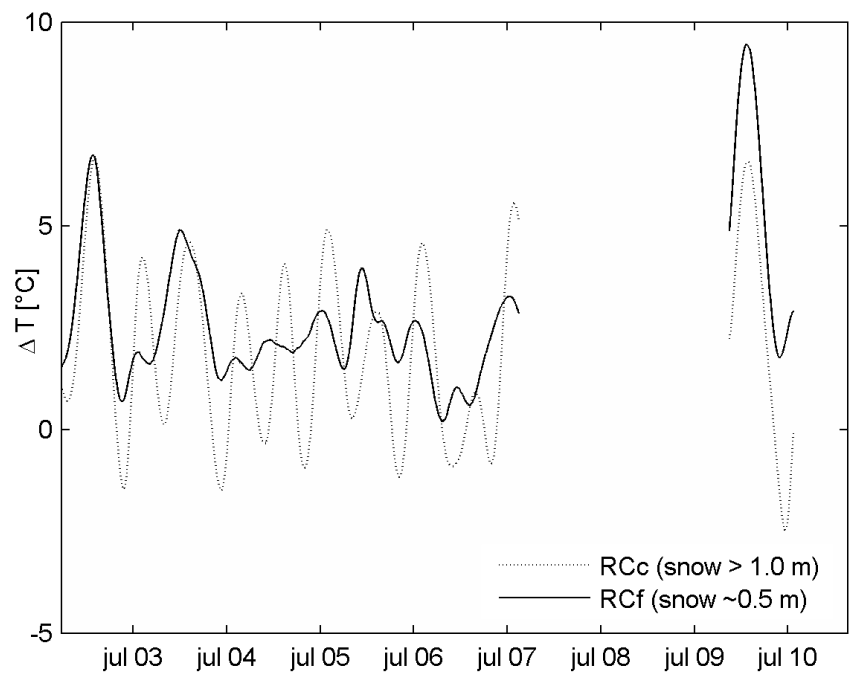

Fig. 5. Temperature differences between ground surface temperature and air temperature for a site with a maximum snow cover of $1 \mathrm{~m}$ and a site with a thin snow cover of around $0.5 \mathrm{~m}$.

almost linear temperature decrease with depth in summer (respectively increase in winter). At both sites the mean annual temperature is higher than the mean summer temperature below $4 \mathrm{~m}$ depth, which is due to the phase lag by depth and to the different time intervals of the mean summer and mean annual temperature. The TSc site (Fig. 7c) shows a large temperature gradient within the first meter and a smaller gradient from 1-6 m depth. Below $3.5 \mathrm{~m}$, the eight-year mean temperatures are around $0^{\circ} \mathrm{C}$ throughout the year. All rock glacier sites (Fig. 7d-f) show a split temperature profile, including an upper part (active layer) with a high temperature gradient and the permanently frozen part below with almost homogeneous temperatures. At the RCc and RMc sites (Fig. 7e and $\mathrm{f}$ ), the temperature within the permafrost body varies between -2.3 (winter mean) and $-0.5^{\circ} \mathrm{C}$ (summer mean). The temperature of the rock glacier front (RCf Fig. 7d) remains always around $0^{\circ} \mathrm{C}$.

To analyse the seasonal influence of the surface and subsurface material, cumulative degree days (CDD) were calculated and shown in Fig. 8. Starting at the first of October of each year, the daily mean temperatures were summed up for one year and presented as a four-year mean. Cumulative degree days give evidence about the yearly balance of a thermal regime. In permafrost, the CDD should be negative over the course of one year, and for positive CDD, seasonal frost can be assumed. Figure 8a presents CDD of the surface of different materials and of the air temperature at $2 \mathrm{~m}$ height. Even though the cumulative mean air temperature is clearly negative, all sites apart from RMc show positive CDD at the surface $(0 \mathrm{~m})$. The largest cumulative temperature difference is between the air temperature and the temperature of the bedrock site Bv $(1626 \mathrm{~K})$. At all sites the CDD within the thaw layer increase much faster during summer than the

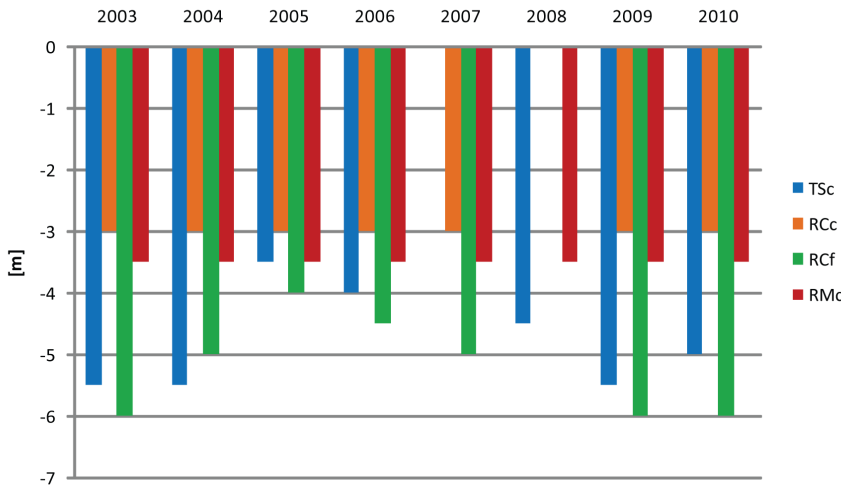

Fig. 6. Active layer depth of the last eight years for the boreholes with permafrost.

temperatures are decreasing in winter (Fig. 8b). Hence, the thermal permafrost regime remains stable if the higher number of freezing degree days compensates the faster increase of summer temperatures. This is only observed at the rock glacier sites, which show a clear negative temperature trend at a depth of $2.5 \mathrm{~m}$. The TSc and the RCf sites are close to $0 \mathrm{~K}$, which is mainly caused by a much smaller temperature decrease in winter (Fig. 8b). Comparing the two boreholes of the Chastelets rock glacier (RCc and RCf), CDD for RCf are $792 \mathrm{~K}$ higher than for RCc. Although the temperature increase during summer is the same, RCf experiences less cooling during winter.

Presenting cumulative degree days at $5 \mathrm{~m}$ depth in Fig. $8 \mathrm{c}$, permafrost and seasonal frost regimes can be differentiated. The only sites with a stable permafrost regime are the coarse blocky rock glaciers (RMc and RCc). The TSc and the RCf sites have an intermediate regime close to $0 \mathrm{~K}$.

By comparing the bare and the vegetated bedrock sites (Fig. 9a, b), the Bv site shows $50 \mathrm{~K}$ higher cumulative degree days, but a smaller amount of freezing degree days $(126 \mathrm{~K})$ and a smaller amount of thawing degree days $(77 \mathrm{~K})$ than $\mathrm{Bb}$. Although the borehole is only covered by $19 \mathrm{~cm}$ of soil and vegetation, this effect has an impact on the thermal regime down to $>1 \mathrm{~m}$ depth (Fig. 9c).

The differences of the snow cover (duration and height) as well as the yearly freezing and thawing periods are listed in detail for the uppermost sensors at each borehole in Table 2. In winter 2010/2011 the variation of the height of the snow cover was between $1.57 \mathrm{~m}(\mathrm{RMc}), 1.4 \mathrm{~m}(\mathrm{Bv})$ and $0.5 \mathrm{~m}$ (RCf). The interannual variation of the snow cover height at the RMc site was between $0.57 \mathrm{~m}(2006 / 2007)$ and $1.83 \mathrm{~m}$ (2008/2009) (see as well Fig. 3). The mean duration of the snow cover varies from 167 days (RCf) to 205 days (RCc). All sites show a standard deviation of about 40 days.

Concerning the freezing degree days, the rock glacier sites (RCc and RMc) showed a mean of 250 days each year, which is much more than the seasonal frost sites (Bb and Bv). During the years 2005 and 2006, all sites experienced 
Table 2. Comparison of the snow cover (duration and height) and freezing and thawing indicators for the last eight years and for different sites for $1.5 \mathrm{~m}$ depth. Freezing indicators are the cumulative freezing temperature gradient (CFTG), the annual amount of freezing degree days and the duration of the spring zero curtain. Thawing indicators are expressed by the cumulative thawing temperature gradient (CTTG) and the annual amount of thawing degree days. Values are calculated for hydrological years (i.e. 2003 starts on 1 October 2002).

\begin{tabular}{|c|c|c|c|c|c|c|c|c|}
\hline \multirow[b]{2}{*}{ Site } & \multirow[b]{2}{*}{ Year } & \multicolumn{3}{|c|}{ Freezing indicators } & \multicolumn{2}{|c|}{ Thawing indicators } & \multicolumn{2}{|c|}{ Snow cover } \\
\hline & & $\begin{array}{c}\text { Duration } \\
\text { of spring zero } \\
\text { curtain }[\mathrm{d}]\end{array}$ & $\begin{array}{c}\text { Cumulative freezing } \\
\text { temperature gradient } \\
\text { (CFTG) }\left[\mathrm{Kd}^{-1}\right]\end{array}$ & $\begin{array}{l}\text { Amount of } \\
\text { freezing } \\
\text { degree days }\end{array}$ & $\begin{array}{c}\text { Cumulative thawing } \\
\text { temperature gradient } \\
\text { (CTTG) }\left[\mathrm{Kd}^{-1}\right]\end{array}$ & $\begin{array}{l}\text { Amount of } \\
\text { thawing } \\
\text { degree days }\end{array}$ & $\begin{array}{c}\text { Duration of } \\
\text { snow cover } \\
\text { [d] }\end{array}$ & $\begin{array}{c}\text { Snow } \\
\text { depth } \\
(\max )[\mathrm{m}]\end{array}$ \\
\hline \multirow[t]{8}{*}{$\mathrm{Bb}$} & 2003 & 2 & -0.13 & 84 & 11.3 & 279 & 205 & - \\
\hline & 2004 & - & - & - & - & - & - & - \\
\hline & 2005 & 5 & -5.37 & 163 & 8.41 & 197 & 146 & - \\
\hline & 2006 & 1 & -4.59 & 186 & 8.84 & 178 & 114 & - \\
\hline & 2007 & - & - & - & - & - & 132 & - \\
\hline & 2008 & - & - & - & - & - & 171 & - \\
\hline & 2009 & 0 & 0 & 0 & 9.56 & 365 & 211 & 1.4 \\
\hline & 2010 & 0 & 0 & 0 & 9.16 & 365 & 211 & 1.3 \\
\hline \multicolumn{2}{|c|}{ Mean (stdev) } & $2( \pm 2)$ & $-2.02( \pm 2.72)$ & $61( \pm 88)$ & $9.45( \pm 1.11)$ & $277( \pm 89)$ & $170( \pm 40)$ & - \\
\hline \multirow[t]{8}{*}{$\mathrm{Bv}$} & 2003 & 4 & -0.13 & 51 & 10.8 & 310 & 200 & - \\
\hline & 2004 & - & - & - & - & - & - & - \\
\hline & 2005 & 1 & -3.09 & 187 & 8.4 & 177 & 149 & - \\
\hline & 2006 & 1 & -2.92 & 200 & 8.92 & 164 & 127 & - \\
\hline & 2007 & - & - & - & - & - & 132 & - \\
\hline & 2008 & - & - & - & - & - & 177 & - \\
\hline & 2009 & 0 & -0.03 & 79 & 9.87 & 286 & 229 & 1.5 \\
\hline & 2010 & 1 & -0.05 & 100 & 8.77 & 264 & 221 & 1.4 \\
\hline \multicolumn{2}{|c|}{ Mean (stdev) } & $1( \pm 2)$ & $-1.24( \pm 1.61)$ & $128( \pm 53)$ & $9.35( \pm 0.97)$ & $240( \pm 66)$ & $176( \pm 42)$ & - \\
\hline \multirow[t]{8}{*}{$\mathrm{TSc}$} & 2003 & 10 & -0.07 & 121 & 5.9 & 234 & 214 & - \\
\hline & 2004 & - & - & - & - & - & - & - \\
\hline & 2005 & 6 & -3.02 & 206 & 3.29 & 153 & 188 & - \\
\hline & 2006 & 5 & -3.78 & 225 & 2.91 & 135 & 148 & - \\
\hline & 2007 & - & - & - & - & - & 169 & - \\
\hline & 2008 & - & - & - & - & - & 200 & - \\
\hline & 2009 & 4 & -0.07 & 142 & 4.92 & 219 & 257 & - \\
\hline & 2010 & 8 & -0.84 & 177 & 3.38 & 180 & 247 & - \\
\hline \multicolumn{2}{|c|}{ Mean (stdev) } & $7( \pm 2)$ & $-1.56( \pm 1.73)$ & $187( \pm 42)$ & $4.08( \pm 1.27)$ & $184( \pm 42)$ & $203( \pm 40)$ & - \\
\hline \multirow[t]{8}{*}{$\mathrm{RMc}$} & 2003 & - & - & - & - & - & 199 & 1.69 \\
\hline & 2004 & 21 & -3.31 & 237 & 5.48 & 108 & 221 & 1.38 \\
\hline & 2005 & 19 & -4.79 & 209 & 4.86 & 137 & 147 & 0.81 \\
\hline & 2006 & 26 & -5.64 & 218 & 5.27 & 121 & 110 & 0.93 \\
\hline & 2007 & - & - & - & - & - & 124 & 0.57 \\
\hline & 2008 & 25 & -4.33 & 226 & 5.65 & 115 & 182 & 1.24 \\
\hline & 2009 & - & - & - & - & - & 227 & 1.83 \\
\hline & 2010 & 17 & -3.73 & 236 & 5.84 & 112 & 216 & 1.57 \\
\hline \multicolumn{2}{|c|}{ Mean (stdev) } & $22( \pm 4)$ & $-4.36( \pm 0.91)$ & $254( \pm 10)$ & $5.42( \pm 0.38)$ & $119( \pm 11)$ & $178( \pm 46)$ & $1.25( \pm 0.45)$ \\
\hline \multirow[t]{8}{*}{$\mathrm{RCc}$} & 2003 & 44 & -1.39 & 224 & 6.82 & 97 & 224 & - \\
\hline & 2004 & 41 & -2.55 & 229 & 4.44 & 96 & 258 & - \\
\hline & 2005 & 21 & -5.23 & 225 & 4.33 & 119 & 171 & - \\
\hline & 2006 & 24 & -6.11 & 217 & 4.15 & 124 & 141 & - \\
\hline & 2007 & 29 & -3.86 & 174 & 5.56 & 162 & 188 & - \\
\hline & 2008 & - & - & - & - & - & 201 & - \\
\hline & 2009 & - & - & - & - & - & - & - \\
\hline & 2010 & 43 & -3.4 & 236 & 3.95 & 86 & 252 & - \\
\hline \multicolumn{2}{|c|}{ Mean (stdev) } & $34( \pm 10)$ & $-3.76( \pm 1.73)$ & $251( \pm 28)$ & $4.88( \pm 1.11)$ & $114( \pm 28)$ & $205( \pm 43)$ & - \\
\hline \multirow[t]{8}{*}{ RCf } & 2003 & 40 & -0.98 & 181 & 6.25 & 144 & 195 & - \\
\hline & 2004 & 38 & -1.77 & 152 & 5.94 & 176 & 219 & - \\
\hline & 2005 & 33 & -4.43 & 142 & 5.23 & 190 & 136 & - \\
\hline & 2006 & 14 & -3.49 & 157 & 6.36 & 194 & 107 & - \\
\hline & 2007 & 39 & -2.58 & 116 & 5.36 & 210 & 129 & - \\
\hline & 2008 & - & - & - & - & - & 169 & - \\
\hline & 2009 & - & - & - & - & - & - & - \\
\hline & 2010 & 43 & -0.32 & 32 & 6.78 & 290 & 211 & 0.5 \\
\hline \multicolumn{2}{|c|}{ Mean (stdev) } & $35( \pm 11)$ & $-2.26( \pm 1.55)$ & $165( \pm 49)$ & $5.99( \pm 0.60)$ & $201( \pm 49)$ & $167( \pm 44)$ & - \\
\hline
\end{tabular}



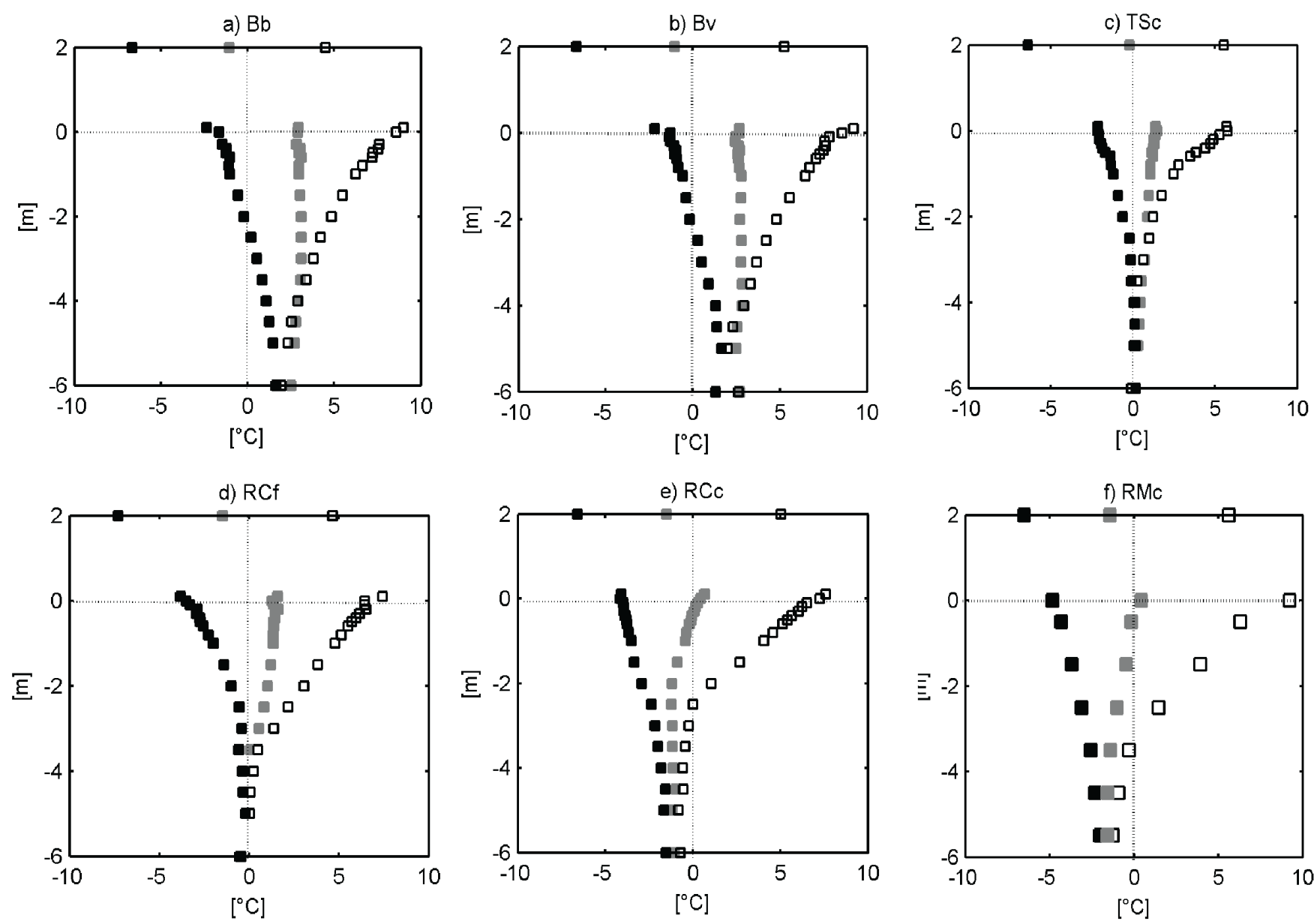

Fig. 7. Eight-year mean annual (grey), mean summer (white) and mean winter temperatures (black) for each borehole and each depth. In addition, air temperature (taken from the micrometeorological station at rock glacier Murtèl) and the individual mean GST at each borehole site are included.

the strongest freezing (i.e. the highest cumulative freezing temperature gradient (CFTG)). During the warm summer in 2003, the cumulative thawing temperature gradient (CTTG) was only slightly increased, whereas the CFTG was at all sites one of the lowest during the last eight years. In general, the cumulative freezing temperature gradient was lower than the cumulative thawing temperature gradient at all sites and in all years, except in the year 2006 where at the rock glacier and the talus slope places the CFTG exceeded the CTTG. At each site the annual change of the CFTG was higher (standard deviation between 0.91 and 2.72) than the annual change of the CTTG, with a standard deviation between 0.38 and 1.27.

\subsection{Apparent thermal diffusivity (ATD)}

Figure 10 presents the calculated ATD for different sites and depths. Only values below $1 \mathrm{~m}$ depth will be discussed, because the temperature amplitude close to the surface is influenced by energy balance parameters rather than by thermal properties of the subsurface. The ATD of the bedrock increases with depth to values up to $1.64 \times 10^{-6} \mathrm{~m}^{2} \mathrm{~s}^{-1}$, which agrees well with the values of Robert (1998), who found $1.7 \times 10^{-6} \mathrm{~m}^{2} \mathrm{~s}^{-1}$ as value for granitic rock at a MAST of around $7.2^{\circ} \mathrm{C}$. ATD values found within the active layer of the Chastelets rock glacier $(1-3 \mathrm{~m})$ are about $2.69 \times$ $10^{-6} \mathrm{~m}^{2} \mathrm{~s}^{-1}$ and therefore higher than within the ice-filled permafrost layer underneath $\left(1.3 \times 10^{-6} \mathrm{~m}^{2} \mathrm{~s}^{-1}\right)$. The permafrost layer of RMc (3-5 m) shows with $1.56 \times 10^{-6} \mathrm{~m}^{2} \mathrm{~s}^{-1}$ similar values (Fig. 10). These values are slightly higher than the ones published by Williams and Smith (1989), where pure ice is given by a value of $1.16 \times 10^{-6} \mathrm{~m}^{2} \mathrm{~s}^{-1}$ at $0^{\circ} \mathrm{C}$. The talus slope has the largest annual range of the ATD $\left(2 \times 10^{-6}\right.$ $3.45 \times 10^{-6} \mathrm{~m}^{2} \mathrm{~s}^{-1}$ ).

Figure 11 presents the calculated temperature transfer rate for different sites. As expected, the rock glacier sites (RCc and $\mathrm{RMc}$ ) have the fastest temperature transfer, followed by the talus slope and by the bedrock and fine-grained sites. The ice below the active layer enhances the temperature gradient 
a) $0 \mathrm{~m}$

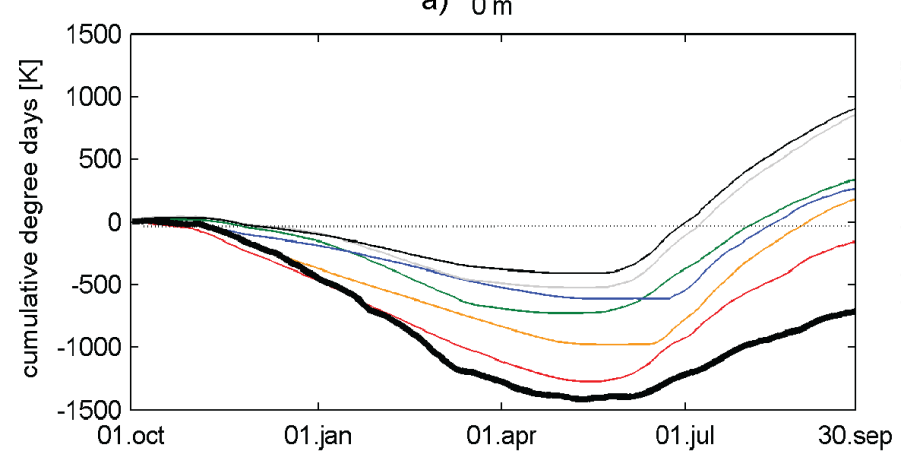

c) $-5 m$

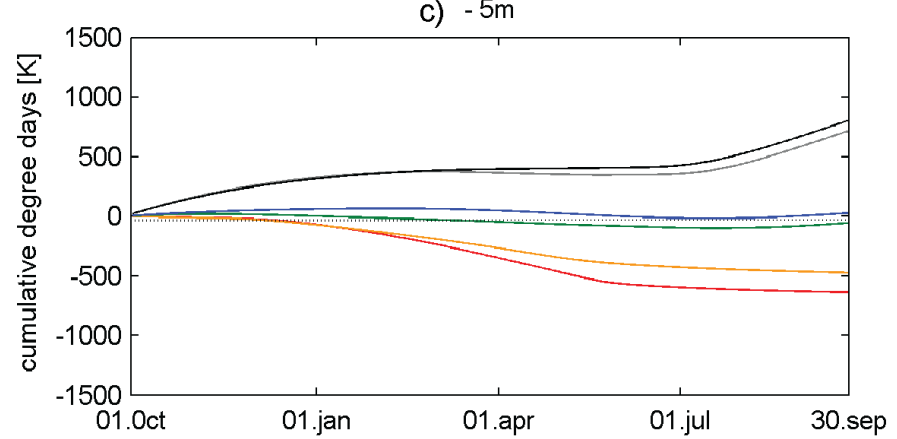

b) $-2.5 m$

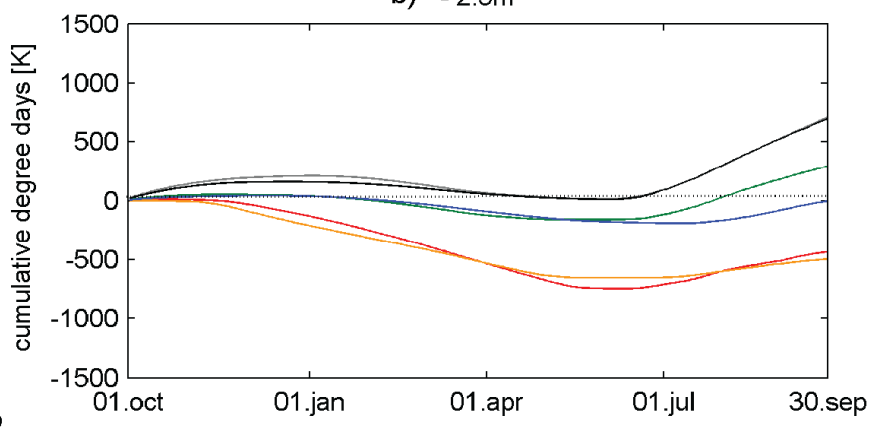

Fig. 8. Mean cumulative degree days (averaged over four years $(2003,2005,2006,2010)$ ) at three different depths $(0 \mathrm{~m}(\mathbf{a}), 2.5 \mathrm{~m}(\mathbf{b})$ and $5 \mathrm{~m}(\mathbf{c}))$ for the six boreholes. The air temperature is shown for comparison.

a)

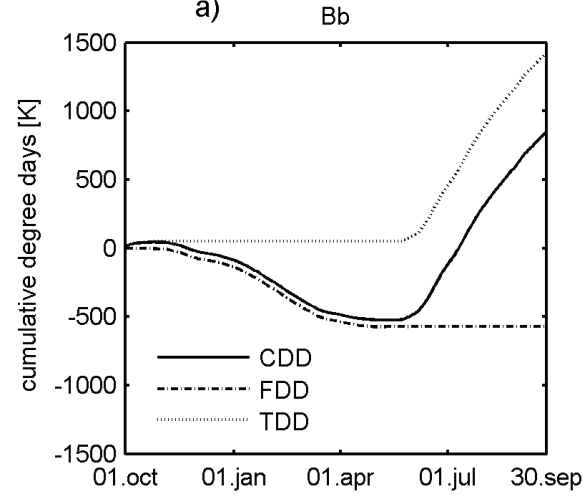

b) Bv

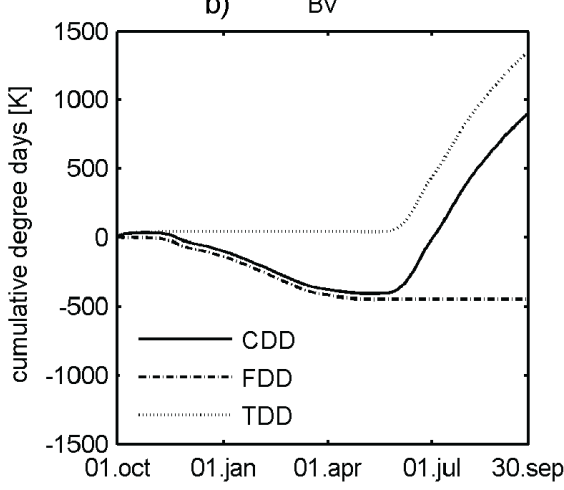

c) $\mathrm{Bb}-\mathrm{Bv}$

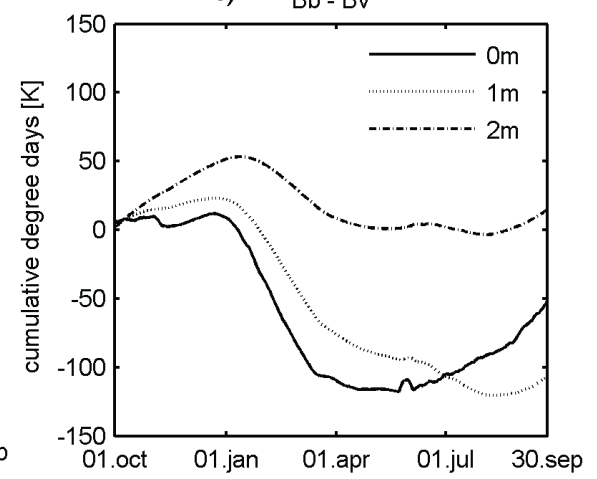

Fig. 9. Cumulative degree days (CDD) (averaged over four years $(2003,2005,2006,2010)$ ) at the surface $(0 \mathrm{~m}$ depth) for bare bedrock (Bb) (a) and vegetated bedrock (Bv) (b). Freezing degree days (FDD) are all days $\leq 0{ }^{\circ} \mathrm{C}$, whereas the days with temperatures $>0{ }^{\circ} \mathrm{C}$ were set to 0 . Likewise, the thawing degree days (TDD) are the days with temperatures $>0{ }^{\circ} \mathrm{C}$ so temperatures $\leq 0^{\circ} \mathrm{C}$ were set to 0 . For (c) the mean cumulated temperature difference between the vegetated and the bare bedrock site for $0 \mathrm{~m}, 1 \mathrm{~m}$ and $2 \mathrm{~m}$ depth was calculated.

and therefore the temperature transfer rate by a factor of four (up to $5.6 \mathrm{~K} \mathrm{~m}^{-1} \mathrm{~d}^{-1}$ ) compared to the ice-free sites.

\section{Discussion}

Compared to other studies on mountain permafrost which recognized an ongoing degradation (Harris et al., 2009; Smith et al., 2010; Farbrot et al., 2011) and a temperature rise of up to $0.095^{\circ} \mathrm{Ca}^{-1}$ (subsurface temperature at 6-9 m depth) from 1999 to 2009 (Isaksen et al., 2011), the investigated sites within the Murtèl-Corvatsch area show no consistent subsurface temperature trends since 2002 within the observed range of depth. Rather, the thermal regime is mainly influenced by the composition of the subsurface material and the height and duration of the snow cover (Fig. 5). At all sites the subsurface temperatures were the lowest when the snow height was less than $1 \mathrm{~m}$ (Table 2 and Fig. 3). This agrees well with other field (Keller and Gubler, 1993) and 


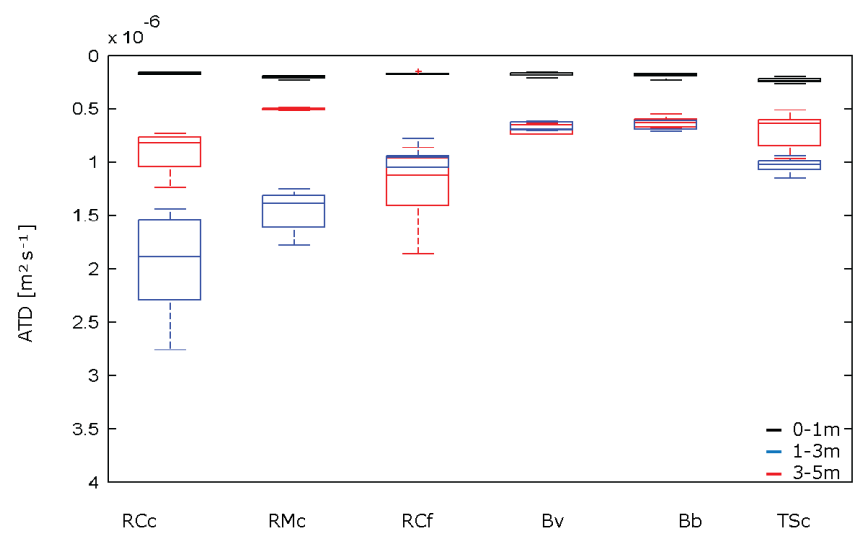

Fig. 10. ATD of the different sites. Calculated for the surface (black), the upper layer (blue) and the lower layer (red).

modelling studies (Luetschg et al., 2008), which determined the value of $>0.8 \mathrm{~m}$ for an insulating snow cover. Isaksen et al. (2011) confirmed the correlation between the height of the snow cover and the subsurface temperatures for the observed Norwegian permafrost sites. Concerning the duration of the snow cover, it is about 1 month longer at the coarse blocky sites (TSc and RCc) than at the other sites (Table 2). Given that all boreholes are placed at the same altitude, it can be assumed that the first snow arrives at all sites at the same time. Therefore, the variation in snow cover duration is mainly due to a higher and longer lasting snow cover between the blocks. At the different sites the maximum snow height varies between $0.5 \mathrm{~m}$ and $1.57 \mathrm{~m}$. Luetschg et al. (2008) showed that the height of the snow cover is the most important influencing factor on the ground thermal regime, followed by the effect of the date of the first insulating snow cover.

The findings of Luetschg et al. (2008) could be confirmed, showing that the longer the non-insulating snow cover lasts in autumn, the colder is the GST through the entire year. At all sites the cooling during autumn/winter and the duration of the zero curtain in spring had a stronger influence on the interannual variability of the thermal regime than temperature increase during summer (Table 2 and Fig. 8). Even though the cumulative mean air temperature is clearly negative, the cumulative degree days at the surface at all sites (apart from $\mathrm{RMc}$ ) were positive due to the isolating effect of the snow cover in winter.

In the following the dominant processes and material characteristics are discussed for each site:

- Bedrock: The two bedrock sites (Bb and Bv) showed only seasonal frost within the investigated range of depth and increased temperatures were observed in 2003, 2008 and 2009. At the Bb site (below $5 \mathrm{~m}$ depth), no freezing was observed during the last two years (Fig. 3a). Thermal conduction was the dominant process, as could be seen from the almost linear tempera-

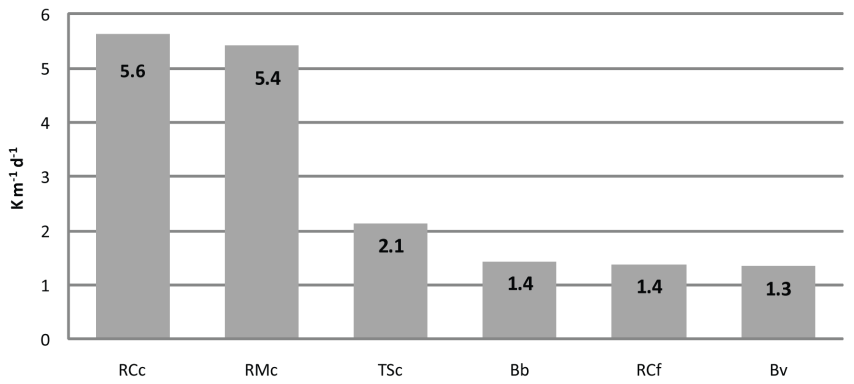

Fig. 11. Temperature transfer rate, calculated as 6-year mean from maximum summer borehole temperatures from $0.5 \mathrm{~m}$ depth to the lower limit of the active layer in $\mathrm{K} \mathrm{m}^{-1} \mathrm{~d}^{-1}$.

ture decrease with depth (Fig. 7), the high cumulative thawing temperature gradient (CTTG) $\left(9.4^{\circ} \mathrm{C} \mathrm{day}^{-1}\right)$ and the calculated ATD of about $1.64 \times 10^{-6} \mathrm{~m}^{2} \mathrm{~s}^{-1}$. Comparing the vegetated with the bare bedrock site revealed that the $\mathrm{Bv}$ site shows $50 \mathrm{~K}$ higher cumulative mean temperatures, but a smaller amount of freezing degree days $(126 \mathrm{~K})$ and a smaller amount of thawing degree days $(77 \mathrm{~K})$ than $\mathrm{Bb}$. Consequenly, the bare bedrock site experiences a higher incoming shortwave radiation during the day and a higher outgoing longwave radiation during the night. These two radiation fluxes seem to counteract in a quite homogenous way, whereas the Bv site dampens the daily temperature fluctuation due to a higher heat storage capacity of the soil (Walker et al., 2003), leading to a more balanced but slightly warmer regime. Consequently, the impact of the heat storage capacity on the annual thermal regime is more important than a slightly higher incoming solar radiation. This effect had an impact on the thermal regime to more than $1 \mathrm{~m}$ depth (Fig. 9c).

- Rock glacier (coarse blocky): The coarse blocky, icerich rock glacier sites (RCc and $\mathrm{RMc}$ ) showed no significant changes in the thermal regime during the entire observation period (Figs. 3 and 6). Their temperature profile is split into a high temperature gradient whithin the active layer and almost isothermal temperature conditions of the ice down to $6 \mathrm{~m}$ depth. In summer 2009 the thermistor chain of the RCc borehole was cut at about $4 \mathrm{~m}$ depth due to the movement of the rock glacier. Hence, it can be assumed that a shear horizon is at $4 \mathrm{~m}$ depth, $1.5 \mathrm{~m}$ below the top of permafrost. The active layer depth of the two rock glaciers did not change during the last eight years (Fig. 6) and the temperature gradient within the active layer is the largest in comparison with the other sites (Fig. 7). According to Smith et al. (2010), the thermal regime seems to be strongly influenced by the comparatively high ice content, causing only little variation of the active layer depth in spite of changing climate parameters. ATD values found within 
the active layer of the Chastelets rock glacier $(1-3 \mathrm{~m})$ are about $2.69 \times 10^{-6} \mathrm{~m}^{2} \mathrm{~s}^{-1}$ and therefore higher than within the ice-filled permafrost layer underneath $(1.3 \times$ $10^{-6} \mathrm{~m}^{2} \mathrm{~s}^{-1}$ ), caused by a higher amount of air filled pore spaces. The ATD values of the active layer and the high temperature transport rate of $5.6 \mathrm{~K} \mathrm{~m}^{-1} \mathrm{~d}^{-1}$ (Fig. 11) confirm a high thermal response of the active layer. Hooke (1998) pointed out that, at a temperature of $-0.5^{\circ} \mathrm{C}$, variations of the ATD are mainly caused by changes in thermal conductivity, which are slightly decreasing with increasing temperatures. On the other hand, the heat capacity is increasing because of a continuously rising unfrozen water content within the ice. However, real conditions influencing the ATD of rock glaciers are even more complicated because heat capacity is also dependent on the concentration of impurities in the ice, and the thermal conductivity is influenced by the ratio of ice/rock.

- Rock glacier (fine-grained): The fine-grained site at the frontal part of the Chastelets rock glacier (RCf) became ice free in 2008 or 2009 (see Fig. 3d). The variable active layer depth within the observed period of time and the temperature of the ice close to $0{ }^{\circ} \mathrm{C}$ illustrate the high sensitivity of this site. In the year 2008/2009, the remaining ice in the front of the rock glacier melted out completely (Fig. 3d), probably due to 3-D influenced topography of the rockglacier front (Fig. 1). The high temperature gradient within the active layer (Fig. 7d) was probably caused by the cold temperatures of the adjacent ice of the rock glacier. The duration of the zero curtain seems to be very important for this site, as it reduces the thawing period. In contrast to Farbrot et al. (2011) and Isaksen et al. (2011) who found enhanced ground cooling at exposed sites with a thin noninsulating snow cover, this site does not seem to experience stronger cooling of the subsurface by the penetration of cold air, even though it is the one with the smallest snow depth $(0.5 \mathrm{~m})$. The GST Fig. 3d) during winter is not lesser than at the other rock glacier sites. Therefore other processes, such as advection caused by infiltrating (melt-) water as well as the amount and size of pore spaces, seem to be more important for fine-grained material.

- Talus slope: A longer lasting snow cover and a reduced amount of incoming shortwave radiation, due to the slightly more shaded position between the blocks, caused a much longer frozen season (Figs. 3c, 7c) and lower cumulative temperatures at the surface $(4.9 \mathrm{~K})$ (Table 2) than at the bedrock sites close-by. Relatively low MAAT during the years 2005 and 2006 (Fig. 3, PERMOS, 2007) caused a shallow active layer depth, whereas during the years 2003 and 2009, the active layer depth increased about $2 \mathrm{~m}$ due to a relative high MAAT (Fig. 3, PERMOS, 2010). The varying zero curtain in spring (Table 2) indicated a highly variable year-to-year production of ice during autumn/winter. However, the high interannual variability of active layer depth (Fig. 6) and the highly variable ATD values lead to the assumption that this site had a yearly changing amount of ice/water within the air-filled pore spaces but contained only very little ice during summer. The high ATD values (on average $2.73 \times 10^{-6} \mathrm{~m}^{2} \mathrm{~s}^{-1}$ ) and the low annual temperature variation below $1 \mathrm{~m}$ depth confirm that this site is mainly influenced by nonconductive processes as discussed in Delaloye and Lambiel (2005), Lambiel and Pieracci (2008). Advective cooling by air flow between the blocks seemed to be efficient below $1 \mathrm{~m}$ depth and caused low temperatures throughout the year. Within the first meter a temperature transfer rate of about $2.1 \mathrm{~K} \mathrm{~m}^{-1} \mathrm{~d}^{-1}$ was observed (Fig. 11). As explained by Hanson and Hoelzle (2005), the first meter of this borehole was drilled in a block of approximately $1 \mathrm{~m}$ depth, leading to the assumption that the uppermost part of the borehole is dominated by conductive processes. Hence, the occurrence of permafrost at this site is due to the very efficient cooling by convective processes and the seasonal creation of ice.

\section{Conclusions}

Eight-year borehole temperature data from a high alpine permafrost environment including different subsurface materials were presented. Assuming that the microclimate, the exposition and slope angle are almost the same for all sites, no uniform subsurface temperature changes were observed. The thermal response depends strongly on the (sub-) surface material and its site-specific processes as follows:

- At all sites the interannual variability of the freezing during autumn/winter and the duration of the zero curtain in spring have a stronger influence on the annual thermal regime than temperatures during summer.

- At the investigated Murtèl-Corvatsch area, temperature anomalies, like in the year 2003 (PERMOS, 2007), are not due to a stronger temperature increase during summer but rather to the low freezing during the winter before.

- The height of the snowpack has an influence on all sites. A thin snowpack without thermal resistance (i.e. during winter 2004/2005 and 2005/2006) forces a cooling of the ground irrespective of the subsurface material. An insulating snow cover was observed with snow depths $>1 \mathrm{~m}$. The duration of the snow cover is about one month longer at the coarse blocky sites.

- Within fine-grained material with a thermal regime close to $0^{\circ} \mathrm{C}$, the duration of the zero curtain seems to be a key factor for the thermal regime. Although the 
site with of the fine-grained material has the smallest maximal snow depth $(0.5 \mathrm{~m})$, this site experiences less freezing than coarse blocky material.

- Ice-rich material enhances the temperature transport rate significantly due to a high temperature gradient. However, as long as the temperature of the ice is between 0 and $-1^{\circ} \mathrm{C}$, the energy is used for phase change processes and no significant changes in active layer depth will occur.

- Within coarse blocky material, the air ventilation and the seasonal production of ice are the main factors for permafrost occurrence in high alpine regions. While temperatures within the talus slope are close to $0^{\circ} \mathrm{C}$ and a stable permafrost regime is observed, the thermal regime of the fine-grained site (where convective and advective airflow can be neglected) thawed in 2008/2009.

- A vegetation and soil layer dampens the annual temperature amplitude deeper than $1 \mathrm{~m}$. However, in total, the annual mean ground temperatures are higher as a result of the higher heat storage capacity of the soil.

Especially fine-grained material and material with small amounts of ice at a temperature of $0^{\circ} \mathrm{C}$ are highly sensitive to changes in the microclimate, but these are not yet sufficiently investigated at these sites. The understanding of the processes during the phase change and its effect on different physical parameters is still challenging. Within finegrained material, numerous complex processes like the infiltration of melt(-water), refreezing water during summer and air-circulation depending on the pore spaces are involved, which should be further investigated by combined modelling and field studies.

Acknowledgements. The authors wish to express their thanks to the PERMOS network which provided the Murtèl borehole data, the Corvatsch AG for their friendly logistic support, Hansueli Gubler for its technical help and advice, the SPCC-project (Sensitivity of Mountain Permafrost to Climate Change, DFG HA3475/3-1) for financial support of the field work, Reynald Delaloye and Ketil Isaksen for the helpful discussions, the editor Dan Riseborough for its constructive comments and lastly all who have contributed by the data aquisition in the field. This investigation was funded by the University of Fribourg, Switzerland.

Edited by: D. Riseborough

\section{References}

Balch, E. S.: Glaciers or freezing caverns, Allen, Lane and Scott, Philadelphia, 1900.

Barsch, D.: Ein Permafrostprofil aus Graubünden, Schweizer Alpen, Zeitschrift fuer Geomorphologie, 21, 79-86, 1977.
Delaloye, R.: Contribution à l'étude du pergélisol de montagne en zone marginale, Ph.D. thesis, Fac. Sciences, Université de Fribourg, GeoFocus 10, 2004.

Delaloye, R. and Lambiel, C.: Evidence of winter ascending air circulation throughout talus slopes and rock glaciers situated in the lower belt of alpine discontinous permafrost (Swiss Alps), Norwegian Journal of Geography, 59, 194-203, 2005.

Delaloye, R., Reynard, E., Lambiel, C., Marescot, L., and Monnet, R.: Thermal anomaly in a cold scree slope, Creux du Van, Switzerland, in: 8th International Conference on Permafrost, pp. 175-180, Zürich, 2003.

Farbrot, H., Hipp, T., Etzelmueller, B., Isaksen, K., Strand Odegard, R., Schuler, T., and Humlum, O.: Air and ground temperature variation observed along elevation continentality gradients in southern Norway, Permafrost and Periglacial Processes, 22, 343-360, 2011.

Gruber, S. and Haeberli, W.: Permafrost in steep bedrock slopes and its temperature-related destabilization following climate change, J. Geophys. Res., 112, F02S18, doi:10.1029/2006JF000547, 2007.

Gruber, S. and Hoelzle, M.: The cooling effect of coarse blocks revisited, in: Proceedings of the 9th International Conference on Permafrost, edited by: Kane, D. L. and Hinkel, K. M., vol. 1, pp. 557-561, 2008.

Haeberli, W.: Die Basistemperatur der winterlichen Schneedecke als möglicher Indikator für die Verbreitung von Permafrost in den Alpen, Z. Gletscherkd. Glazialgeolog., 9, 221-227, 1973.

Haeberli, W., Huder, J., Keusen, H., Pika, J., and Röthlisberger, H.: Core drilling through rock glacier-permafrost, in: 5th International Conference on Permafrost, pp. 937-942, Tapir Publishers, 1988.

Hanson, S. and Hoelzle, M.: The thermal regime of the active layer at the Murtèl rock glacier based on data from 2002, Permafrost and Periglacial Processes, 15, 273-282, 2004.

Hanson, S. and Hoelzle, M.: Installation of a shallow borehole network and monitoring of the ground thermal regime of a high alpine discontinuous permafrost environment, Norsk Geografisk Tidsskrift - Norwegian Journal of Geography, 59, 84-93, 2005.

Harris, S. H. and Pedersen, D. E.: Thermal regime beneath coarse blocky material, Permafrost and Periglacial Processes, 9, 107120, 1998.

Harris, C., Arenson, L., Christiansen, H., Etzelmueller, B., Frauenfelder, R., Gruber, S., Haeberli, W., Hauck, C., Hoelzle, M. Humlum, O., Isaksen, K., Kaeaeb, A., Kern-Luetschg, M., Lehning, L., Matsuoka, N., Murton, Noetzli, J., Phillips, M., Ross, N., Seppaelae, M., Springman, S., and Vonder Muehll, D.: Permafrost and climate in Europe: Monitoring and modelling thermal, geomorphological and geotechnical responses, Earth-Sci. Rev., 92, 117-171, 2009.

Hasler, A., Gruber, S., and Haeberli, W.: Temperature variability and offset in steep alpine rock and ice faces, The Cryosphere, 5, 977-988, doi:10.5194/tc-5-977-2011, 2011.

Herz, T., King, L., and Gubler, H.: Microclimate within coarse debris of talus slopes in the alpine periglacial belt and its effect on permafrost, in: 8th International Conference on Permafrost, pp. 383-387, 2003.

Hinkel, K. and Outcalt, S.: Identification of heat-transfer process during soil cooling, freezing and thaw in central alaska, Permafrost and Periglacial Processes, 5, 217-235, 1994. 
Hoelzle, M. and Gruber, S.: Borehole and Ground Surface Temperatures and their relationship to meteorological conditions in the Swiss Alps, in: Proceedings of the 9th International Conference on Permafrost, edited by: Kane, D. L. and Hinkel, K. M., vol. 1, pp. 723-728, 2008.

Hoelzle, M., Vonder Muehll, D., and Haeberli, W.: Thirty years of permafrost research in the Corvatsch-Furtschellas area, Eastern Swiss Alps: a review, Norsk Geografisk Tidsskrift - Norwegian Journal of Geography, 56, 137-145, 2002.

Hooke, R.: Principles of glacier mechanics, Simon and Schuster/A Viacom Company, 1998.

Isaksen, K., Odegard, R., Etzelmueller, B., Hilbich, C., Hauck, C., Farbrot, H., Eiken, T., Hygen, H., and Hipp, T.: Degrading mountain permafrost in southern Norway: spatial and temporal variability of mean ground temperatures, 1999-2009, Permafrost and Periglacial Processes, 22, 361-377, 2011.

Keller, F. and Gubler, H.: Interaction between snow cover and high mountain permafrost, Murtèl-Corvatsch, Swiss Alps, in: Proceedings of the 6th International Conference on Permafrost, 59 July, 1993, edited by: Cheng, G., pp. 332-337, South China University of Technology Press, Guangzhou, 1993.

Krautblatter, M. and Hauck, C.: Electrical resistivity tomography monitoring of permafrost in solid rock walls, J. Geophys. Res., 112, F02S20, doi:10.1029/2006JF000546, 2007.

Lambiel, C. and Pieracci, K.: Permafrost distribution in talus slopes located within the alpine periglacial belt, Swiss Alps, Permafrost and Periglacial Processes, 19, 293-304, 2008.

Lewkowicz, A.: Evaluation of miniature temperature-loggers to monitor snowpack evolution at permafrost sites, Northwestern Canada, Permafrost and Periglacial Processes, 19, 323-331, 2008.

Ling, F. and Zhang, T.: Impact of the timing and duration of seasonal snow cover on the active layer and permafrost in the Alaskan Arctic, Permafrost and Periglacial Processes, 14, 141$150,2003$.

Luetschg, M., Lehning, M., and Haeberli, W.: A sensitivity study of influencing warm/thin permafrost in the Swiss Alps, J. Glaciol., 54, 696-704, 2008.

Mittaz, C., Hoelzle, M., and Haeberli, W.: First results and interpretation of energy-flux measurements of Alpine permafrost, Ann. Glaciol., 31, 275-280, 2000.

Morard, S., Delaloye, R., and Dorthe, J.: Seasonal thermal regime of a mid-latitude ventilated debris accumulation, in: Proceedings of the 9th International Conference on Permafrost, edited by: Kane, D. L. and Hinkel, K. M., vol. 1, pp. 1233-1238, Institute on Northern Engineering, University of Alaska, Fairbanks, 2008.

Outcalt, S., Nelson, F., and Hinkel, K.: The zero-curtain effect: heat and mass transfer across an isothermal region in freezing soil, Water Resour. Res., 26, 1509-1516, 1990.

Panz, M.: Analyse von Austauschprozessen in der Auftauschicht des Blockgletschers Murtèl-Corvatsch, Oberengadin, Master's thesis, Ruhr Universität (unpubl.), 2006.
PERMOS: Permafrost in Switzerland 2002/2003 and 2003/2004, Glaciological Report (Permafrost), vol. 4/5 of Permafrost Monitoring Switzerland (PERMOS), Cryospheric Commission, edited by: Vonder Muehll, D., Noetzli, J., Roer, I., Makowski, K., and Delaloye, R., University of Zurich, 2007.

PERMOS: Permafrost in Switzerland 2006/2007 and 2007/2008, Glaciological Report (Permafrost), vol. 8/9 of Permafrost Monitoring Switzerland (PERMOS), Cryospheric Commission, edited by: Noetzli, J. and Vonder Muehll, D., University of Zurich, 2010.

Pogliotti, P., Cremonese, E., Morra di Cella, U., Gruber, S., and Giardino, M.: Thermal diffusivity variability in alpine permafrost rock walls, in: Proceedings of the 9th International Conference on Permafrost, edited by: Kane, D. L. and Hinkel, K. M., vol. 2, pp. 1427-1432, 2008.

Robert, S. A.: Near-surface thermal profiles in alpine bedrock: implications for the frost weathering of rock, Arctic and Alpine Research, 30, 362-372, 1998.

Sawada, Y., Ishikawa, M., and Yugo, O.: Thermal regime of sporadic permafrost in a block slope on Mt. NishiNupukaushinupuri, Hokkaido Island, Northern Japan, Geomorphology, 53, 121-130, 2003.

Scherler, M., Hauck, C., Hoelzle, M., Staehli, M., and Voelksch, I.: Melt-water infiltration into the frozen active layer at an alpine permafrost site, Permafrost and Periglacial Processes, 21, 325334, 2010.

Smith, M. W. and Riseborough, D. W.: Permafrost monitoring and detection of climate change, Permafrost and Periglacial Processes, 7, 301-309, 1996.

Smith, S., Romanovsky, V., Lewkowicz, A., Burn, C., Allard, M., Clow, G., Yoshikawa, K., and Throop, J.: Thermal state of permafrost in North America: a contribution to the international polar year, Permafrost and Periglacial Processes, 21, 117-135, 2010.

Wakonigg, H.: Unterkühlte Schutthalden. Beiträge zur Permafrostforschung in Österreich, in: Arbeiten aus dem Institut für Geographie, vol. 33, pp. 209-223, Karl-Franzens-Universität, 1996.

Walker, D. A., Jia, G., Epstein, H., Raynolds, M., Chapin III, F., Copass, C., Hinzman, L., Knudson, J., Maier, H., Michaelson, G., Nelson, F., Ping, C., Romanovsky, V., and Shiklomanov, N.: Vegetation-soil-thaw-depth relationships along a Low-Artic bioclimate gradient, Alaska: Synthesis of information from the ATLAS studies, Permafrost and Periglacial Processes, 14, 103-123, 2003.

Wegmann, M., Gudmundsson, G. H., and Haeberli, W.: Permafrost changes in rock walls and the retreat of alpine glaciers: a thermal modelling approach, Permafrost and Periglacial Processes, 9, 23-33, 1998.

Williams, P. J. and Smith, M. W.: The frozen earth - fundamentals of geocryology, Cambridge University Press, 1989. 